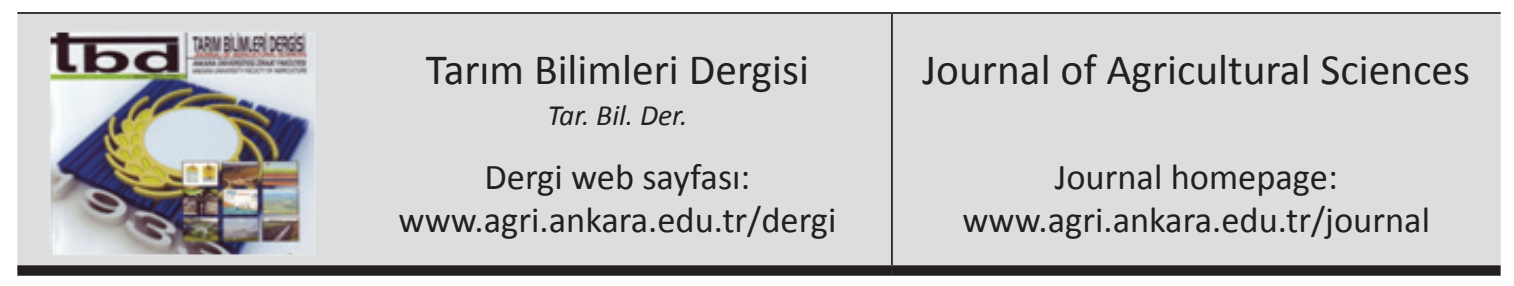

\title{
Türkiye'de Yetiştirilen Bazı Yerli Koyun Irklarında Kalpastatin (CAST) Geni Polimorfizminin PCR-RFLP Yöntemiyle Belirlenmesi
}

\author{
Murat Soner BALCIOĞLU ${ }^{a}$, Taki KARSLI ${ }^{a}$, Emine ŞAHİN ${ }^{b}, Z^{2}$ afer ULUTAŞc, Yüksel AKSOY ${ }^{d}$ \\ ${ }^{a}$ Akdeniz Üniversitesi, Ziraat Fakültesi, Zootekni Bölümü, Kampüs, Antalya, TÜRKIYYE \\ ${ }^{b}$ Akdeniz Üniversitesi, Korkuteli Meslek Yüksekokulu, Antalya, TÜRKIYE \\ ${ }^{c}$ Niğde Üniversitesi, Tarım Bilimleri ve Teknolojileri Fakültesi, Niğde, TÜRKIYYE

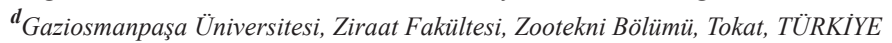

\section{ESER BILGISII}

Araştırma Makalesi DOI: 10.1501/Tarimbil_0000001301

Sorumlu Yazar: Murat Soner BALCIOĞLU, E-posta: msoner@akdeniz.edu.tr, Tel: +90 (242) 3102446

Geliş Tarihi: 27 Aralık 2013, Düzeltmelerin Gelişi: 01 Mart 2014, Kabul: 15 Mart 2014

\section{ÖZET}

Bu çalışmada, Türkiye'de yetiştirilen 7 yerli koyun ırkında kalpastatin (CAST) gen polimorfizmi PCR-RFLP metodu kullanılarak araştırılmıştır. CAST geninin M ve N allelleri frekansları; Kangal ( $n=31)$, İvesi ( $n=26)$, Güney Karaman $(\mathrm{n}=23)$, Akkaraman $(\mathrm{n}=21)$, Morkaraman $(\mathrm{n}=34)$, Karayaka $(\mathrm{n}=33)$ ve Karakaş $(\mathrm{n}=22)$ koyun irklarında sırasıyla 0.92 $0.08,0.59-0.41,0.67-0.33,0.69-0.31,0.87-0.13,0.86-0.14,0.89-0.11$ olarak tespit edilmiştir. Ki-kare testi CAST geni bakımından Morkaraman, İvesi ve Karayaka populasyonlarının Hardy-Weinberg dengesinden önemli düzeyde $(\mathrm{P}<0.05)$ saptığını, diğer populasyonların ise Hardy-Weinberg dengesinde olduğunu göstermiştir.

Anahtar Kelimeler: Kalpastatin geni; Polimorfzim; PCR-RFLP; Koyun

\section{Determination of Calpastatin (CAST) Gene Polimorphism in Some Native Sheep Breeds Reared in Turkey by PCR-RFLP Method}

\section{ARTICLE INFO}

Research Article

Corresponding Author: Murat Soner BALCIOĞLU, E-mail: msoner@akdeniz.edu.tr, Tel: +90 2423102446

Received: 27 December 2013, Received in Revised Form: 01 March 2014, Accepted: 15 March 2014

\begin{abstract}
In this study, calpastatin (CAST) gene polimorphism was investigated in 7 native sheep breeds reared in Turkey by using PCR-RFLP method. The frequencies of M and N alleles of CAST gene in Kangal ( $\mathrm{n}=31)$, Awassi ( $\mathrm{n}=26)$, Güney Karaman $(n=23)$, Akkaraman $(n=21)$, Morkaraman $(n=34)$, Karayaka $(n=33)$, and Karakas $(n=22)$ sheep breeds were determined as $0.92-0.08,0.59-0.41,0.67-0.33,0.69-0.31,0.87-0.13,0.86-0.14,0.89-0.11$ respectively. According to chi-square test, all the other populations were consistent with Hardy-Weinberg equilibrium, whereas Morkaraman, İvesi and Karayaka populations showed significant $(\mathrm{P}<0.05)$ deviation from Hardy-Weinberg equilibrium for the CAST gene. Keywords: Calpastatin gene; Polymorphism; PCR-RFLP; Sheep
\end{abstract}




\section{Giriş}

Geçtiğimiz son yirmi yılda moleküler genetik alanında yaşanan gelişmeler çiftlik hayvanları yetiştirme ve sslah programlarında değişikliklere yol açmıştır. Moleküler markerler çiftlik hayvanlarında DNA seviyesinde genetik varyasyonun ortaya çıkarılmasında, gen bölgeleri ile ekonomik önemi olan karakterlerin ilişkilendirilmesinde (QTL) ya da herhangi bir özelliği etkileyen tek bir genin (majör gen) ortaya çıkarılmasında yoğun olarak kullanılmaktadır. Moleküler markerler ile elde edilen bilgiler ise Marker Destekli Seleksiyon (Marker Assisted SelectionMAS) çalışmalarında kullanılmaktadır. Özellikle sığır, koyun keçi gibi generasyonlar arası sürenin uzun olduğu türlerde MAS tek başına ya da klasik 1slah yöntemleriyle birlikte kullanılabilmektedir.

Son yıllarda çiftlik hayvanlarında değişik ekonomik özellikler ile ilişkili MAS çalışmalarında kullanılabilecek çok sayıda aday gen tespit edilmiştir. Koyunculukta MAS çalışmalarında kullanılabilecek başlıca genler arasında; döl verimi ile ilişkili olan BMPR-IB, BMP-15, GDF-9 (Karslı \& Balcıŏlu 2010; Karslı et al 2012; Chu et al 2011), Prolaktin (Chu et al 2007), Melatonin (Hernandez et al 2005) genleri, et verimi ile ilişkili olan Myostatin (Tellam et al 2012), İnsülin benzeri büyüme faktörü (IGF-I) (He et al 2012), IGF bağlayıcı protein (IGF-BP) (Kumar et al 2006), büyüme hormonu $(\mathrm{GH})$ genleri (Adams \& Briegel 2005) ve süt kalitesi ile ilişkili olan $\beta$ - Lactoglobulin geni (Şahin et al 2011) gösterilebilir. Son zamanlarda çiftlik hayvanlarında, bu genlere et verim ve kalitesi ile ilgili olduğu bildirilen kalpain (CAPN1) ve kalpastatin (CAST) genleri de eklemiştir (Gao et al 2007; Dagong et al 2012; Kania 2012; Şahin et al 2013).

Etin kalitesi; görünüş, renk, tat, koku, yağ içeriği, tekstür ve yumuşaklık (gevreklik) gibi birkaç önemli özelliğe bağlıdır. Kesim sonrası etin yumuşaklığı hayvanın ölüm öncesi metabolik durumuna, hayvanın genetik alt yapısına, kas proteinlerine ve çevresel faktörlere bağlıdır. Kesim sonrası etin yumuşamasında birkaç önemli etkenden birisi de ölüm sonrası kas proteinlerindeki proteolizin oranıdır (Ciobanu et al 2004).

Kalpain sisteminin protein yıkımının düzenlenmesi, miyoblast göçü, normal iskelet kas gelişimi ve büyüme gibi çeşitli fizyolojik işlemlerde önemli rolü vardır. Kalpain sistemi 3 molekülden oluşmaktadır. Bunlardan ikisi kas hücrelerinde tespit edilmiş hücre içi $\mathrm{C}^{2+}$ bağımlı proteolitik enzimler olan $\mu$ - ve m-kalpain, üçüncüsü ise kalpain etkisini inhibe edici özellikte endojen bir protein olan kalpastatindir. Koyunlarda beşinci kromozom üzerinde bulunan CAST geni kas gelişiminde ve kesim sonrası etin yumuşamasında önemli rol oynar (Zhou et al 2007; Djadid et al 2011; Gharahveysi et al 2012).

Kalpastatin seviyesindeki artış kalpain aktivitesinin düşmesine neden olur. Bu durum ise kas protein degredasyonunu artırarak kas büyüme oranını azaltmakta veya kesim sonrası etin yumuşamasını hızlandırmaktadır (Goll et al 1998). Moleküler seviyede kalpastatin proteini $76 \mathrm{kDa}$ ağırlığındadır ve 5 domainden oluşmaktadır (Suleman et al 2012). Kalpastatin kalpain haricinde diğer proteazları inhibe etmez ve kalpainler ile birlikte sitozolde ve membranda bulunur (Kaya 2005).

Sığırlarda yapılan çalışmalarda, CAST genindeki varyasyon ile karkas ve et kalite özellikleri arasında ilişki tespit edilmiştir (Casas et al 2006; Schenkel et al 2006). Bunun yanı sira koyunlarda da CAST geninde varyasyon olduğu bildirilmiştir (Palmer et al 1998; Sutikno et al 2011). PCR-RFLP metodu kullanılarak yapılan önceki çalışmalarda koyun CAST geninde 2 allel (M ve N) (Sutikno et al 2011; Palmer et al 1998), PCR-SSCP metodu kullanılarak yapılan çalışmalarda ise 3 allel (A, B, C) tanımlanmış ve $C$ alleli ile et kalite özellikleri arasındaki ilişki olduğu bildirilmiştir (Schenkel et al 2006).

$\mathrm{Bu}$ çalışmada Türkiye'de yetiştirilen bazı koyun irklarında CAST geni polimorfizminin ortaya çıkarılması, gen ve genotip frekanslarının belirlenmesi amaçlanmıştır.

\section{Materyal ve Yöntem}

\subsection{Materyal}

Araştırma Türkiye'nin değişik bölgelerinde yetiştirilen Akkaraman ( $\mathrm{n}=21)$, Güney Karaman $(\mathrm{n}=23)$, Kangal $(\mathrm{n}=31)$, Karayaka $(\mathrm{n}=33)$, Karakaş $(n=22)$, İvesi $(n=26)$, Morkaraman $(n=34)$ yerli 
koyun ırklarının yetiştirildiği sürülerden rastgele toplanan 190 örnek üzerinde yürütülmüştür. Akkaraman rrkı örnekleri Konya, Güney Karaman ırkı örnekleri Antalya, Kangal ırkı örnekleri Sivas, Karayaka ırkı örnekleri Tokat, Karakaş ırkı örnekleri Van, İvesi ve Morkaraman ırklarının örnekleri ise Erzurum illerinden toplanmıştır.

\subsection{Kan örneklerinin alınmast ve DNA ekstraksiyonu}

DNA ekstraksiyonu için kullanılacak kan örnekleri hayvanların boyun toplar damarından (vena jugularis) steril tek kullanımlık iğneler ile $10 \mathrm{~mL}$ 'lik EDTA'lı tüplere alınmıştır. Alınan kan örnekleri DNA ekstraksiyonu yapılıncaya kadar $-20{ }^{\circ} \mathrm{C}$ 'de korunmuştur.

Genomik DNA ekstraksiyonu, ticari bir DNA ekstraksiyon kiti (Sigma Aldrich, USA, NA 2020-1KT) kullanılarak yapılmıştır. DNA ekstraksiyonunun başarılı olup olmadığının kontrolü için \% 1'lik agaroz jel kullanılmıştır. Daha sonra elde edilen DNA'ların miktarı spektrofotometre ile belirlenmiş ve DNA'lar PCR uygulaması için 50 ngx $\mu \mathrm{l}^{-1}$ olacak şekilde ayarlanmıştır.

\subsection{PCR-RFLP işlemi}

PCR işlemi 96 kuyucuklu Eppendorf marka Thermal Cycler cihazında gerçekleştirilmiştir. PCR işlemi için daha önce yapılan benzer çalışmalar (Sutikno et al 2011; Palmer et al 1998; Mohammadi et al 2008) incelenmiş ve aşağıdaki PCR programı ve içeriği laboratvuar koşullarında optimize edilmiştir. PCR programı; ilk denatürasyon $95^{\circ} \mathrm{C}$ 'de 5 dakika, denatürasyon $95^{\circ} \mathrm{C}$ 'de 1 dakika, bağlanma $60^{\circ} \mathrm{C}$ ' de 1 dakika, uzama $72{ }^{\circ} \mathrm{C}$ 'de 2 dakika, son uzama ise $72^{\circ} \mathrm{C}$ 'de 10 dakika olacak şekilde ayarlanmış ve 30 döngü uygulanmıştır. PCR reaksiyon karışımı; $5 \mu \mathrm{L} 10 \mathrm{X}$ buffer (pH: 8.5), $3 \mu \mathrm{L} \mathrm{MgCl}_{2}(25 \mu \mathrm{M})$, $4 \mu \mathrm{L}$ dNTPs $(2.5 \mu \mathrm{M})$, 1U Taq DNA polimeraz (MBI Fermentas), forward primer $0.5 \mu \mathrm{L}(0.2 \mu \mathrm{M})$, reverse primer $0.5 \mu \mathrm{L}(0.2 \mu \mathrm{M})$ ve $3 \mu \mathrm{L}$ genomik DNA $\left(\sim 50 \mathrm{ngx} \mu \mathrm{L}^{-1}\right)$ olmak üzere toplam $50 \mu \mathrm{l}$ hacminde ayarlanmıştır. PCR işleminde koyun CAST geninin ekzon 1C/1D bölgesinde bulunan ve daha önce tanımlanan (Palmer et al 1998) primerlerle çalışılmıştır. PCR işlemi sonunda 622 bç büyüklüğündeki $1 \mathrm{C}$ ve $1 \mathrm{D}$ ekzon bölgeleri ile bunların arasındaki intron bölgeler $F$ primer: 5' TGGGGCCCAAT-GACGCCATCGATG 3' ve R primer: 5' GGTGGAGCAGCACTTCTGATCACC 3' çifti kullanılarak çoğaltılmıştır.

622 bç büyüklüğündeki $\mathrm{PCR}$ ürünleri $5^{\prime} \mathrm{C} /$ CGG3'-3'GGC/C 5' tanıma bölgesine sahip MspI (Fermentas - Kat.No: ER0541) restriksiyon enzimi (RE) ile kesime (aktivasyon $37{ }^{\circ} \mathrm{C}$ 'de $3 \mathrm{~s}$, inaktivasyon $65{ }^{\circ} \mathrm{C}$ 'de $15 \mathrm{dk}$ ) bırakılmıştır. RFLP işlemi için reaksiyon karışımı $10 \mu \mathrm{L}$ PCR ürünü, $4 \mu \mathrm{L}$ bidistile su $\left(\mathrm{bdH}_{2} \mathrm{O}\right), 2.9 \mu \mathrm{L}$ enzim buffer (1XTango) ve $0.1 \mu \mathrm{L}$ enzim (MspI- 3000U) olacak şekilde toplam $17 \mu \mathrm{L}$ hazırlanmıştır. Kesim ürünleri $\% 2$ 'lik agaroz jele (peqGOLD Universal Agarose) $13.5 \mu \mathrm{L}$ kesim ürünü, $1.5 \mu \mathrm{L}$ boya (Loading Buffer) yüklenmiş ve $100 \mathrm{~V}$ 'da 90 dak yürütülüp ethidium bromide ile muamele edildikten sonra bantlar UV ile görüntülenebilir hale getirilmiştir. Elektroforez işlemi sonunda görüntülenecek olan bantların büyüklüklerini saptamak için 100 bç aralıklarla bant veren $1.5 \mathrm{~kb}$ büyüklüğünde DNA marker (BIORONKat. No:306005) kullanılmıştır. Kesim işleminden sonra koyun CAST geninde 3 genotip oluşmaktadır. MM alleli için 336 ve 286 bç'lik 2 bant, MN alleli için 622,336 ve 286 bç'lik 3 bant $\mathrm{NN}$ alleli için ise 622 bç'lik tek bant elde edilmiştir.

\subsection{Istatistiksel analizler}

İncelenen örneklerde CAST genine ait allel frekanslarının tahmin edilmesinde gen sayma yöntemi kullanılmıştır (Nei 1987). Populasyonlarda CAST geni için Hardy Weinberg dengesinden sapma ki-kare $\left(\chi^{2}\right)$ istatistiği kullanılarak test edilmiştir (Hartl \& Clark 1989).

\section{Bulgular ve Tartışma}

PCR işlemi sonucunda 622 bç'lik bantlar başarı ile çoğaltılmış ve bu PCR ürünleri MspI restriksiyon enzimi ile kesime bırakılmıştır. Kesim işlemi sonucunda MM genotipli bireylerde 336 ve 286 bç'lik 2 bant, MN genotipli bireylerde 622, 336 ve 286 bç'lik 3 bant NN genotipli bireylerde 
ise 622 bç'lik tek bant elde edilmiştir (Şekil 1). Türkiye'nin çeşitli bölgelerinde yetiştirilen değişik koyun ırklarından 190 örnekte yapılan çalışma sonucunda elde edilen sonuçlara göre genotip ve allel frekansları Çizelge 1'de, gözlenen ve beklenen heterozigotluk ile ki-kare testi sonuçları Çizelge 2'de sunulmuştur.

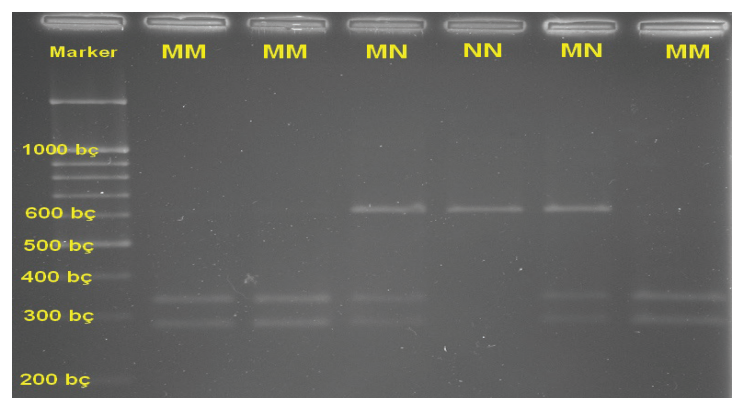

Şekil 1- CAST genotiplerinin \% 2'lik agaroz jelde görüntüsü. MM (336 ve 286 bç), MN (622, 336 ve 286 bç), NN (622 bç)

Figure 1- The illustration of CAST genotypes on 2.5\% agarose gel. MM (336 and $286 \mathrm{bp}), M N(622,336$ and $286 b p), N N(622 b p)$
Elde edilen sonuçlar Türkiye'nin değişik bölgelerinde yetiştiriciliği yapılan 7 koyun ırkının CAST geni bakımından polimorfik olduğunu göstermiştir. Araştırma materyali 7 koyun ırkında CAST geninin $\mathrm{M}$ ve $\mathrm{N}$ allelleri değişen frekanslarda mevcuttur. M allelinin frekansının en yüksek olduğu 1rk Kangal (0.92), en düşük olduğu rrk (0.59) ise İvesi'dir. Tüm koyun irklarında homozigot MM ve heterozigot $\mathrm{MN}$ genotipleri değişen frekanslarda mevcutken homozigot NN genotipi yalnızca Kangal ırkında tespit edilememiştir.

Kangal ve Karakaş ırklarında gözlenen $\mathrm{M}$ ve $\mathrm{N}$ allel frekansları Gabor et al (2009) tarafindan Tsigai (0.91-0.09) ve Tsigai x Lacaune melezlerinde (0.90$0.10)$ ve Suleman et al (2012) tarafindan Thalli (0.90$0.10)$ ve Lohi (0.87-0.13) koyunlarında elde edilen allel frekanslarıyla uyumlu bulunmuştur. Güney Karaman ve Akkaraman ırklarının allel frekansları Gharahveysi et al (2012)'in tarafindan İran'ın Zel koyunlarında saptadıkları frekanslarla $(0.75-0.25)$ benzerdir. Morkaraman ve Karayaka koyunlarında saptanan M ve $\mathrm{N}$ alleli frekansları Khederzadeh (2011)'in Dalagh koyunlarında (0.80-0.20), Kowalczyk et al (2011)'nn Blackheaded Mutton ırkında (0.82-0.18), Mohammadi

Çizelge 1- Türkiye'de yetiştirilen bazı yerli koyun ırklarında CAST geninin allel ve genotip frekansları

Table 1-Allele and genotype frequencies of CAST gene in some native sheep breeds raised in Turkey

\begin{tabular}{|c|c|c|c|c|c|c|}
\hline \multirow{2}{*}{ Irk } & \multirow{2}{*}{$n$} & \multicolumn{3}{|c|}{ Genotip frekanslarl } & \multicolumn{2}{|c|}{ Allel frekansları } \\
\hline & & $M M$ & $M N$ & $N N$ & $M$ & $N$ \\
\hline \multirow{2}{*}{ Kangal } & \multirow{2}{*}{31} & 26 & 5 & 0 & \multirow{2}{*}{0.92} & \multirow{2}{*}{0.08} \\
\hline & & 0.84 & 0.16 & 0 & & \\
\hline \multirow{2}{*}{ İvesi } & \multirow{2}{*}{26} & 13 & 5 & 8 & \multirow{2}{*}{0.59} & \multirow{2}{*}{0.41} \\
\hline & & 0.50 & 0.19 & 0.31 & & \\
\hline \multirow{2}{*}{ Güney Karaman } & \multirow{2}{*}{23} & 12 & 7 & 4 & \multirow{2}{*}{0.67} & \multirow{2}{*}{0.33} \\
\hline & & 0.52 & 0.30 & 0.18 & & \\
\hline \multirow{2}{*}{ Akkaraman } & \multirow{2}{*}{21} & 11 & 7 & 3 & \multirow{2}{*}{0.69} & \multirow{2}{*}{0.31} \\
\hline & & 0.52 & 0.34 & 0.14 & & \\
\hline \multirow{2}{*}{ Morkaraman } & \multirow{2}{*}{34} & 27 & 5 & 2 & \multirow{2}{*}{0.87} & \multirow{2}{*}{0.13} \\
\hline & & 0.79 & 0.15 & 0.06 & & \\
\hline \multirow{2}{*}{ Karayaka } & \multirow{2}{*}{33} & 28 & 1 & 4 & \multirow{2}{*}{0.86} & \multirow{2}{*}{0.14} \\
\hline & & 0.85 & 0.03 & 0.12 & & \\
\hline \multirow{2}{*}{ Karakaş } & \multirow{2}{*}{22} & 18 & 3 & 1 & \multirow{2}{*}{0.89} & \multirow{2}{*}{0.11} \\
\hline & & 0.82 & 0.14 & 0.04 & & \\
\hline
\end{tabular}


Çizelge 2- Gözlenen ve beklenen heterozigotluklar ve Hardy Weinberg dengesi için ki-kare testi

Table 2-Observed and expected heterozigosity and chi-square test for Hardy-Weinberg equilibrium

\begin{tabular}{lcccc}
\hline \multirow{2}{*}{ Irk } & \multicolumn{3}{c}{ Heterozigotluk $^{a}$} & \multirow{2}{*}{$\chi^{2}$} \\
\cline { 2 - 4 } Kangal & $M M$ & $M N$ & $N N$ & $0.254^{\mathrm{b}}$ \\
\multirow{2}{*}{ İvesi } & 26 & 5 & 0 & \\
& 26.23 & 4.56 & 0.21 & $9.306^{\mathrm{c}}$ \\
Güney Karaman & 13 & 5 & 8 & \\
& 9.05 & 12.58 & 4.37 & $1.340^{\mathrm{b}}$ \\
Akkaraman & 12 & 7 & 4 & \\
& 10.33 & 10.17 & 2.5 & $1.011^{\mathrm{b}}$ \\
Morkaraman & 11 & 7 & 3 & \\
& 10.00 & 8.98 & 2.02 & $4.540^{\mathrm{c}}$ \\
Karayaka & 27 & 5 & 2 & \\
& 25.73 & 7.69 & 0.58 & $24.243^{\mathrm{c}}$ \\
Karakaş & 28 & 1 & 4 & \\
& 24.41 & 7.95 & 0.64 & $2.385^{\mathrm{b}}$ \\
\hline
\end{tabular}

a, üst satır, gözlenen değerler; alt satır; beklenen değerler; $\chi^{2}{ }_{0.05: 1,} 3.84$; b, Hardy-Weinberg dengesinden sapma önemsiz; c, HardyWeinberg dengesinden sapma önemli; MM, homozigot genotipler (336 bç, 287 bç); MN, Heterozigot genotipler (336 bç, 336 bç, 287 bç); NN, Homozigot genotipler (622 bç)

et al (2008)'in Arap koyunlarında (0.85-0.15), Nanekarani et al (2011)'in Atabi koyunlarında (0.810.19) ve Sutikno et al (2011)'in Endonezya koyun ırklarında (0.86-0.14) saptadıkları allel frekansları ile benzerdir. İvesi rrkında $\mathrm{M}$ ve $\mathrm{N}$ alleli frekansları (0.59-0.41) benzer çalışmalardakinden farklı çıkmıştır (Gabor et al 2009; Sutikno et al 201; Gharahveysi et al 2012). Bu farkl1lık kullanılan örneklerden ve irk içi varyasyondan kaynaklanmış olabilir. Bu nedenle, İvesi rrkında CAST geni polimorfizminin örnek sayısı artırılarak tekrar incelenmesinin faydalı olacağı düşünülmektedir.

İvesi, Morkaraman ve Karayaka koyun populasyonları CAST geni için Hardy-Weinberg dengesinden sapma göstermiştir $(\mathrm{P}<0.05)$. Bu populasyonlardan en yüksek ki-kare değeri Karayaka ırkında (24.243) saptanmıştır. Karayaka ırkına ait kan örnekleri Tokat ili Merkez Günevi köyünden alınmıştır. Bu ırkta Hardy-Weinberg dengesinden sapmanın nedeni yetiştiricilerin ellerindeki hayvanları Gaziosmanpaşa Üniversitesi Ziraat Fakültesi'nde uzun süre seleksiyonla 1slah edilmiş hayvanlardan temin etmeleri olabilir.

\section{Sonuçlar}

Türkiye'de koyunculuk alanında bu güne kadar yapılan ıslah çalışmaları daha çok ekonomik önemi olan özelliklerin (et, süt, yapağı) miktarının artırılmasına yöneliktir. Ancak günümüzde değişen tüketici talepleri doğrultusunda etin miktarı yanında kalite özelliklerinin de iyileştirilmesi zorunluluk halini almıştır. CAST genindeki polimorfizm ile et kalite özellikleri arasındaki ilişki daha önceki çalışmalarda (Kapelanski et al 2004; Schenkel et al 2006) bildirilmiştir. Bu çalışma ile Türkiye'de yetiştirilen yerli koyun 1rklarında CAST geni polimorfizminin PCR-RFLP yöntemiyle belirlenebileceği gösterilmiştir. PCRRFLP yöntemi CAST genindeki polimorfizmi belirlemedehızlıve ekonomik bir araçtır. Türkiye'de yetiştiriciliği yapılan tüm koyun ırklarında benzer çalışmalar artırılarak devam etmelidir. CAST geni et kalitesinin iyileştirilmesinde Marker Destekli Seleksiyon için aday gen olması bakımından önemlidir. 


\section{Kaynaklar}

Adams N R \& Briegel J R (2005). Multiple effects of an additional growth hormone gene in adult sheep. Journal of Animal Science 83: 1868-1874

Casas E, White S N, Wheeler T L, Shackelford S D, Koohmaraie M, Riley D G, Chase Jr C C, Johnson D D \& Smith T P L (2006). Effects of calpastatin and $\mu$-Kalpain meakers in beef cattle on tenderness traits. Journal of Animal Science 84: 520-525

Chu M X, Mu Y L, Fang L, Ye S C \& Sun S H (2007). Prolactin Receptor as a Candidate Gene for Prolificacy of Small Tail Han Sheep. Animal Biotechnology 18: 65-73

Chu M X, Yang J, Feng T, Cao GL, Fang L, Di R, Huang D W, Tang Q Q, Ma Y H, Li K \& Li N (2011). GDF9 as a candidate gene for prolificacy of Small Tail Han sheep. Molecular Biology Reports 38(8): 5199-5204

Ciobanu D C, Bastiaansen J W M, Lonergan S M, Thomsen H, Dekkers J C M, Plastow G S \& Rothschild M F (2004). New alleles in calpastatin gene are associated with meat quality traits in pigs. Journal of Animal Science 82: 2829-2839

Dagong M I A, Herman R, Sumantri C, Noor R R \& Yamin $M$ (2012). Carcass and physical meat characteristics of thin tail sheep (TTS) based on calpastatin gene (CAST) (Locus intron 5-exon 6) genotypes variation. Journal Ilmu Ternak dan Veteriner 17(1): 13-24

Djadid N D, Nikmard M, Zakeri S \& Gholizadeh S (2011). Characterization of calpastatin gene in Iranian Afshari sheep. Iranian Journal of Biotechnology 9(2): 145-149

Gabor M, Trakovicka A \& Miluchova M (2009). Analysis of Polymorphism of CAST Gene and CLPG Gene in Sheep by PCR-RFLP Method. Lucrari ştiintifice Zootehnie şi Biotehnologii 42(2): 470-476

Gao Y, Zhang R, Hu X \& Li N (2007). Application of genomic technologies to the improvement of meat quality of farm animals. Meat Science 77: 36-45

Gharahveysi S, Ali Abbasi H, Irani M, Abdullahpour R $\&$ Mirhabibi S (2012). Polymorphism investigation of calpastatin gene in Zel sheep population of Iran by PCR-RFLP method. African Journal of Biotechnology 11(13): 3211-3214

Goll D E, Thompson V F, Taylor R G \& Ouali A (1998). The Kalpain system and skeletal muscle growth. Canadian Journal of Animal Science 78: 503-512

Hartl D L \& Clark A G (1989). Principles of Population Genetics. Second Edition. Sinauer Associates, Inc., Sunderland, Massachusetts, pp.37
He J N, Zhang B Y, Chu M X, Wang P Q, Feng T, Cao G L, Di R, Fang L, Huang D W, Tang Q Q \& Li N (2012). Polymorphism of insulin-like growth factor 1 gene and its association with litter size in Small Tail Han sheep. Molecular Biology Reports 39: 9801-9807

Hernandez X, Bodin L, Chesneau D, Guillaume D, Chemineau P, Malpaux P \& Migaud M (2005). Relationship between MT1 melatonin receptor gene polymorphism and seasonal hysiological responses in Île-de-France ewes. Reproduction Nutrition Development 45: 151-162

Kania M G (2012). Effect of calpastatin gene polymorphism on lamb growth and muscling. Annals of Animal Science 12(1): 63-72

Kapelanski W, Grajewska J K, Bocian M, Jankowiak J W (2004). Calpastatin (CAST) gene polymorphism and selected meat quality traits in pig. Animal Science Papers and Reports 22(4): 435-441

Karslı T \& Balcığlu M S (2010). Türkiye'de yetiştirilen alt1 yerli koyun 1rkında BMPR-IB (Booroola) geninde FecB allel varlığının PCR-RFLP yöntemiyle araştırılması. Kafkas Üniversitesi Veteriner Fakültesi Dergisi 16(6): 1033-1036

Karslı T, Şahin E, Karslı B A, Alkan S \& Balcığlu M S (2012). An investigation of mutations (FecXG, FecXI, $\mathrm{FecXH}, \mathrm{FecXB}$ ) on BMP-15 gene in some local sheep breeds raised in Turkey. Akdeniz Üniversitesi Ziraat Fakültesi Dergisi 25(1): 29-33

Kaya M (2005). Bir kalpain inhibitörü olan AK295'in nöroprotektif etkilerinin deneysel spinal kord travması modelinde incelenmesi. Uzmanlık Tezi(Basılmamış). Taksim Eğitim ve Araştırma Hastanesi Beyin ve Sinir Cerrahisi Kliniği, İSTANBUL.

Khederzadeh S (2011). Polymorphism of Calpastatin Gene in Crossbreed Dalagh Sheep Using PCR-RFLP. African Journal of Biotechnology 10(53): 1083910841

Kowalczyk M S, Wisniewska E \& Mroczkowsk S (2011). Polymorphisms of calpastatin gene in sheep. Journal of Central European Agriculture 12(3): 425-432

Kumar P, Choudhary V, Kumar K G, Bhattacharya T K, Bhushan B, Sharma A \& Mishra A (2006). Nucleotide sequencing and DNA polymorphism studies on IGFBP-3 gene in sheep and its comparison with cattle and buffalo. Small Ruminant Research 64: 285-292

Mohammadi M, Beigi Nasiri M T, Alami-Saeid K H, Fayazi J, Mamoee M \& Sadr A S (2008). Polymorphism of calpastatin gene in Arabic sheep 
using PCR- RFLP. African Journal of Biotechnology 7(15): 2682-2684

Nanekarani S, Khederzadeh S \& Kaftarkari M (2011). Genotypic Frequency of Calpastatin Gene in Atabi Sheep by PBR Method. International Conference on Food Engineering and Biotechnology. IPCBEE vol.9, IACSIT Press, Singapoore, pp.189-192

Nei M, (1987). Molecular Evolutionary Genetics. Columbia University Press. New York

Palmer B R, Robert N, Hickford J G H \& Bickerstaffe G (1998). Rapid comunication: PCR-RFLP for MspI and NcoI in the ovine calpastatin gene. Journal of Animal Science 76: 1499-1500

Schenkel F S, Miller S P, Jiang Z, Mandell I B, Ye X, Li H \& Wilton J W (2006). Association of a single nucleotide polymorphism in the calpastatin gene with carcass and meat quality traits of beef cattle. Journal of Animal Science 84: 291-299

Suleman M, Khan S U, Riaz M N, Yousaf M, Shah A, Ishaq R \& Ghafoor A (2012). Calpastatin (CAST) gene polymorphism in Kajli, Lohi and Thalli sheep breeds. African Journal of Biotechnology 11(47): 10655-10660

Sutikno A, Yamin M \& Sumantri C (2011). Association of polymorphisms calpastatin gene with body weight of local sheep in Jonggol, Indonesia. Media Peternakan 34: $1-6$

Şahin E, Karslı T, Elmacı C \& Balcığlu M S (2011). Beta-Lactoglobulin gene types in Turkish fat-tailed sheep breeds. Kafkas Üniversitesi Veteriner Fakültesi Dergisi 17(6): 1031-1033

Şahin Ş, Öner Y \& Elmacı C (2013). Esmer ve Siyah Alaca ırkı sığırlarda bazı ekonomik özellikler ile ilişkili gen bölgelerinin PCR-RFLP tekniği ile incelenmesi. Tarım Bilimleri Dergisi 19: 235-244.

Tellam R L, Cockett N E, Vuacolo T \& Bidwell CA (2012). Genes contributing to genetic variation of muscling in sheep. Frontiers in Genetics 3(164): 1-14

Zhou H, Hicford J G H, Gong H (2007). Polymorphism of the ovine calpastatin gene. Molecular and Cellular Probes 21: 242-244 